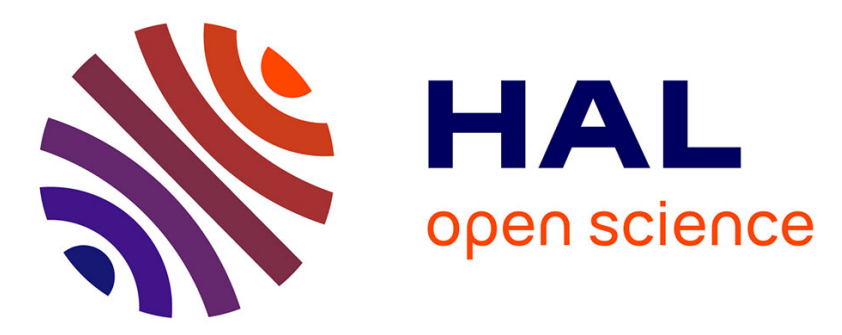

\title{
Response of Streptococcus thermophilus CNRZ368 and its colonial variants to oxidative stress: evidence for an inducible defence system
}

Annabelle Thibessard, Nathalie N. Leblond-Bourget, Annabelle Fernandez, Brigitte Gintz, Bernard Decaris

\section{To cite this version:}

Annabelle Thibessard, Nathalie N. Leblond-Bourget, Annabelle Fernandez, Brigitte Gintz, Bernard Decaris. Response of Streptococcus thermophilus CNRZ368 and its colonial variants to oxidative stress: evidence for an inducible defence system. Le Lait, 2001, 81 (1-2), pp.311-316. 10.1051/lait:2001134 . hal-00895483

\section{HAL Id: hal-00895483 https://hal.science/hal-00895483}

Submitted on 1 Jan 2001

HAL is a multi-disciplinary open access archive for the deposit and dissemination of scientific research documents, whether they are published or not. The documents may come from teaching and research institutions in France or abroad, or from public or private research centers.
L'archive ouverte pluridisciplinaire HAL, est destinée au dépôt et à la diffusion de documents scientifiques de niveau recherche, publiés ou non, émanant des établissements d'enseignement et de recherche français ou étrangers, des laboratoires publics ou privés. 


\title{
Response of Streptococcus thermophilus CNRZ368 and its colonial variants to oxidative stress: evidence for an inducible defence system
}

\author{
Annabelle ThiBessard, Nathalie LEBLOND-Bourget, \\ Annabelle FERnANDEZ, Brigitte GinTZ, Bernard DECARIS*
}

Laboratoire de Génétique et Microbiologie, Unité associée INRA UA 952,

Université Henri Poincaré, boulevard des Aiguillettes, BP 239, 54506 Vandœuvre-lès-Nancy, France

\begin{abstract}
The aerotolerance of Streptococcus thermophilus raises the question of the existence of a defence system against oxidative stress. This work, focused on the strain CNRZ368, provides evidence that such a system actually exists and characterises its inducible and adaptative character. Besides, it shows that survival depends on the physiological state of the culture. Moreover, CNRZ368 is subject to a conditional colonial instability, relying on oxygen conditions: grown under anaerobic conditions, CNRZ368 does not show any polymorphism, whereas under aerobic conditions, four colonial phenotypes can be distinguished. The diffuse phenotype is the predominant one. Ring, edged and opaque phenotypes, constituting almost $1 \%$ of the population, are considered as variant phenotypes. A statistical analysis shows the existence of an enrichment of resistant isolates to oxidative stress among colonial variants.
\end{abstract}

oxidative stress / conditional instability / morphotype / resistance / Streptococcus thermophilus

Résumé - Réponse au stress oxydatif de Streptococcus thermophilus CNRZ368 et de ces variants coloniaux : mise en évidence d'un système de défense inductible. L'aérotolérance de Streptococcus thermophilus soulève la question de l'existence d'un système de défense contre le stress oxydatif. Ce travail, mené sur la souche CNRZ368, montre l'existence d'un tel système ainsi que son caractère inductible et adaptatif. Il montre, de plus, que la survie des cellules en conditions de stress dépend de leur état physiologique. Par ailleurs, la souche CNRZ368 est sujette à une instabilité coloniale conditionnelle, dépendant de la présence d'oxygène. Cultivée en anaérobiose, CNRZ368 ne présente aucun polymorphisme, alors qu'en aérobiose, 4 phénotypes coloniaux peuvent être distingués. Le phénotype diffus est le phénotype majoritaire. Les phénotypes auréolé, pelote et opaque, qui représentent près de $1 \%$ de la population, sont considérés comme des variants phénotypiques. Une analyse statistique montre l'existence d'un enrichissement en isolats résistant à un stress oxydatif au sein de ces variants coloniaux.

stress oxydatif / instabilité conditionnelle / morphotype / résistance / Streptococcus thermophilus

* Correspondence and reprints

Tel.: (33) 3839120 96; fax: (33) 3839125 00; e-mail: decaris @ nancy.inra.fr 


\section{INTRODUCTION}

Oxidative stress can be defined as an excess of reactive oxygen forms in the cell. There are different types of oxygen reactive molecules (including $\mathrm{O}_{2}{ }^{\cdot-}, \mathrm{H}_{2} \mathrm{O}_{2}, \mathrm{OH}^{-}$). These molecular species are naturally and inevitably produced during aerobic metabolism [7, 8, 10, 13]. Their accumulation can provoke damages to DNA $[11,15]$, proteins [4-6] and lipids [9].

Aerobic organisms have developed defence systems that allow them either to neutralise these undesirable products before they reach a toxic level, or to repair their effects. Besides, all oxidative molecules are not equivalent: $\mathrm{O}_{2}{ }^{--}$and $\mathrm{H}_{2} \mathrm{O}_{2}$ are known to induce two distinct regulons (SoxRS and

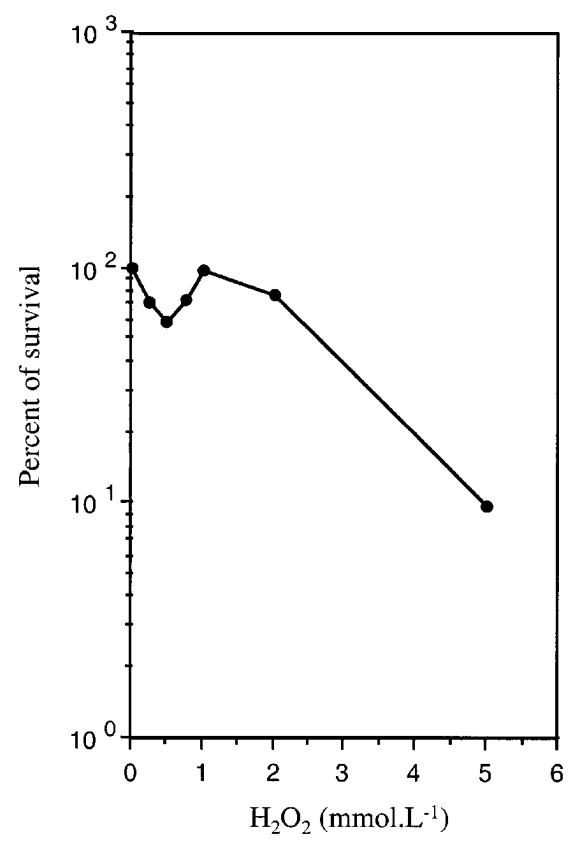

Figure 1. Sensitivity to killing by $\mathrm{H}_{2} \mathrm{O}_{2}$. Survival of CNRZ368 was determined by plating appropriate dilutions of samples after a $15 \mathrm{~min}$ exposure to $\mathrm{H}_{2} \mathrm{O}_{2}$ of exponentially growing cells $\left(\mathrm{OD}_{600 \mathrm{~nm}}=0.6\right)$. Surviving fractions were calculated relatively to colony counts without treatment.
OxyR, respectively) in Salmonella typhimurium and E. coli [3].

Streptococcus thermophilus is an anaerobic aero-tolerant organism, widely used in dairy product fermentation. During production or conservation of these products, oxidative stress may occur, influencing the survival of some bacterial species and consequently, the balance between bacterial populations. The aero-tolerance of $S$. thermophilus raises the question of the existence of a defence system against oxygen aggression in this species.

\section{CHARACTERISATION OF S. THERMOPHILUS RESPONSE TO OXIDATIVE STRESS}

Considering the dichotomy of E. coli response, the effects of two oxidative agents, $\mathrm{H}_{2} \mathrm{O}_{2}$ and menadione (a superoxide radical generator), have been studied.

\subsection{Response to $\mathrm{H}_{2} \mathrm{O}_{2}$}

\subsubsection{Response to $\mathrm{H}_{2} \mathrm{O}_{2}$ is inducible}

Exponentially growing cells of $S$. thermophilus CNRZ368 $\left(\mathrm{OD}_{600}=0.6\right)$ were exposed for 15 min to a range of $\mathrm{H}_{2} \mathrm{O}_{2}$ concentrations (from 0.25 to $5 \mathrm{mmol} \cdot \mathrm{L}^{-1}$ ), and their survival percent was determined by comparison with a non-treated aliquot. Figure 1 shows that between 0.25 and $0.75 \mathrm{mmol} \cdot \mathrm{L}^{-1}$, cell viability appreciably decreased. At slightly higher concentrations, viability increased, presumably as a result of a defence response, and finally, decreased again because of the saturation of the system. This bipartite curve points out the existence and the inducible character of an $\mathrm{H}_{2} \mathrm{O}_{2}$-response.

\subsubsection{Response to $\mathrm{H}_{2} \mathrm{O}_{2}$ is adaptative}

The effect on cell survival of a pre-exposure to a low dose of $\mathrm{H}_{2} \mathrm{O}_{2}$ prior to a high 


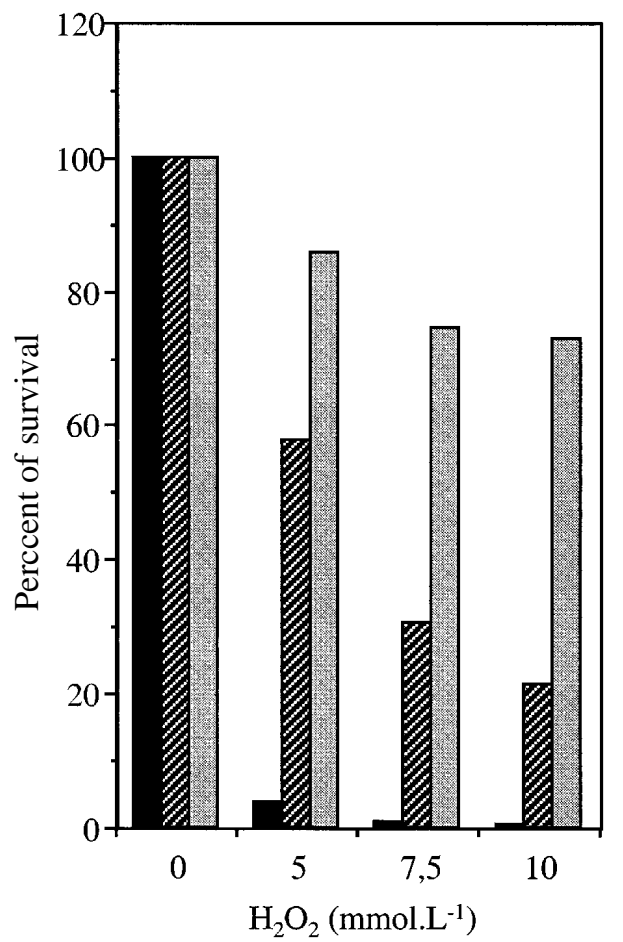

Figure 2. Effect of a $\mathrm{H}_{2} \mathrm{O}_{2}$ pre-treatment on cell survival. Exponentially growing cells were preincubated for $15 \mathrm{~min}$ in the absence $(\boldsymbol{a})$ or the presence of $0.25 \mathrm{mmol} \cdot \mathrm{L}^{-1} \mathrm{H}_{2} \mathrm{O}_{2}(\mathbb{Z})$ or $1 \mathrm{mmol} \cdot \mathrm{L}^{-1} \mathrm{H}_{2} \mathrm{O}_{2}$ (圈). Cells were then treated with higher hydrogen peroxide concentrations. And then, the percent of survival was determined, relatively to an aliquot submitted to the same pre-treatment but not treated.

dose of $\mathrm{H}_{2} \mathrm{O}_{2}$ was investigated. Exponentially growing cells were exposed to $0,0.25$ or $1 \mathrm{mmol} \cdot \mathrm{L}^{-1}$ of $\mathrm{H}_{2} \mathrm{O}_{2}$ for $15 \mathrm{~min}$, and were then exposed to $0,5,7.5$ or $10 \mathrm{mmol} \cdot \mathrm{L}^{-1}$ for $15 \mathrm{~min}$. As shown in Figure 2 , pretreatment of $0.25 \mathrm{mmol} \cdot \mathrm{L}^{-1}$ or of $1 \mathrm{mmol} \cdot \mathrm{L}^{-1}$, has a protective effect facing lethal doses. Thus, when exposed to sublethal doses, CNRZ368 exhibited an adaptative response to $\mathrm{H}_{2} \mathrm{O}_{2}$, as previously demonstrated in E. coli and Salmonella typhimurium $[1,2]$.

\subsubsection{Response to $\mathrm{H}_{2} \mathrm{O}_{2}$ depends on cell physiological state}

The influence of the physiological state of cells facing stress was also tested. A unique culture was divided into several aliquots, which were treated at the beginning, the middle or the end of the exponential phase, or during the stationary phase. The percent of survival to a range of $\mathrm{H}_{2} \mathrm{O}_{2}$ concentrations for these four samples was determined and is presented in Figure 3. The later the culture was treated, the more it resisted $\mathrm{H}_{2} \mathrm{O}_{2}$, until becoming almost insensitive, for tested concentrations, during the stationary phase. Thus, non-growing cells appeared to be more tolerant to $\mathrm{H}_{2} \mathrm{O}_{2}$ than their growing counterparts, as it is already known in E. coli [12].

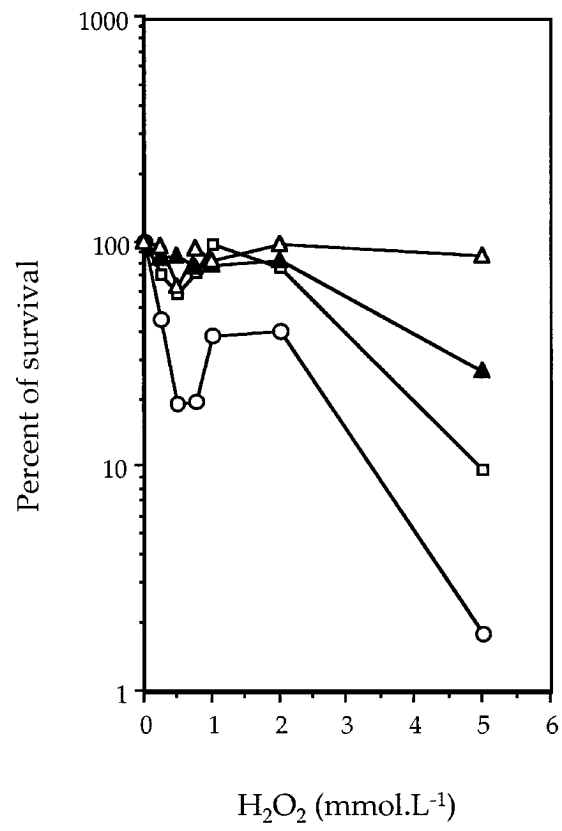

Figure 3. Change of $\mathrm{H}_{2} \mathrm{O}_{2}$ tolerance as a function of physiological state. $\mathrm{H}_{2} \mathrm{O}_{2}$ was added at different times during the ensuing growth period as a function of the $\mathrm{OD}_{600}$. Cells were treated at $\mathrm{OD}_{600 \mathrm{~nm}}=0.15(\bigcirc), \mathrm{OD}_{600 \mathrm{~nm}}=0.60(\square)$, $\mathrm{OD}_{600 \mathrm{~nm}}=0.85(\boldsymbol{\Delta})$ and $\mathrm{OD}_{600 \mathrm{~nm}}=2.10(\triangle)$. 


\subsection{Response to menadione}

Exponentially growing cells of $S$. thermophilus CNRZ368 $\left(\mathrm{OD}_{600}=0.6\right)$ were exposed to a range of concentrations (ranging from 0.5 to $20 \mathrm{mg} \cdot \mathrm{mL}^{-1}$ ) of menadione. Different stress conditions were tested, and it appeared that the exposure of cells to this oxidative agent had to last at least $3 \mathrm{~h}$ to be efficient. The surviving percent was determined by comparison to a non-treated aliquot. A peak of induction was also observed (Fig. 4), and shows that a defence system against menadione exists and is inducible.

Considering the length of this treatment, the effects of pre-exposure to menadione or of the growth phase could not be tested.

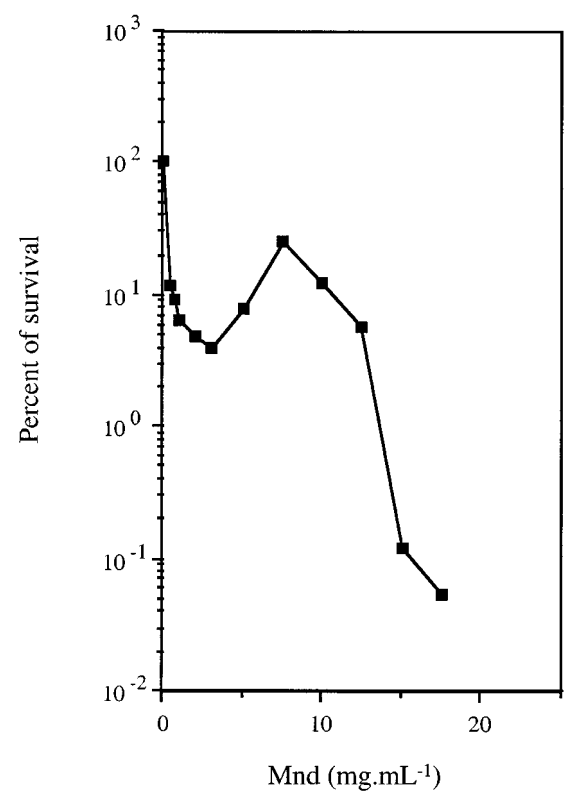

Figure 4. Sensitivity to killing by menadione. Survival was determined by plating appropriate dilutions of samples. These fractions were calculated relative to colony counts without treatment.

\section{COLONIAL PHENOTYPE AND TOLERANCE TO OXIDATIVE STRESS}

S. thermophilus CNRZ368 is subject to a conditional colonial instability that relies on oxygen conditions. In the absence of oxygen, only one colonial phenotype is observed, whereas under aerobic conditions, four phenotypes can be distinguished [14] and are presented in Figure 5. The diffuse phenotype is predominant and represents more than $99 \%$ of the population. Nevertheless, the three others (ring, edged and opaque) constitute almost $1 \%$. When isolates of the four morphological phenotypes of CNRZ368 were plated, the respective colonial phenotype persisted in the majority of each progeny. Nevertheless, colonies with a different phenotype from that of the parent clone were observed. Switching phenomena occurred with proportions ranging from $0.3 \%$ to $11.7 \%$ depending on the phenotype of the plated clone [14].

In order to identify a possible link between this colonial polymorphism and oxidative stress, several isolates of the four phenotypes were subcloned, and tested for their tolerance to menadione. The clone sensitivity level was determined by measurement of the inhibition area produced by a menadione-soaked disc, laid on a confluent lawn.

The inhibition area obtained for the heterogeneous strain CNRZ368 was measured five times and was used as a reference value to compare the values of the 88 tested clones. These five measurements also permitted the evaluation of their reproducibility. The 88 clones were then classified into three groups depending on their menadione tolerance. The first group corresponds to clones which exhibit an inhibition area comparable to that of the strain CNRZ368 and puts together most of the isolates (64/88). The second one reassembles 21 clones which present a smaller inhibition area compared to the strain CNRZ368 showing their 


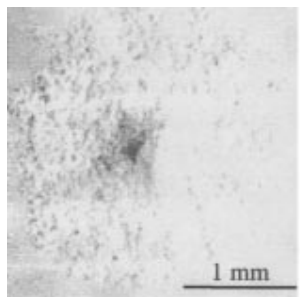

Diffuse

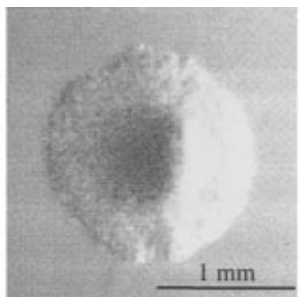

Ring

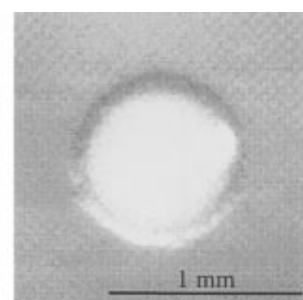

Edged

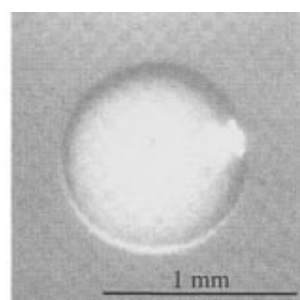

Opaque

Figure 5. Colonial phenotypes of S. thermophilus CNRZ368 in aerobical conditions.

Table I. Resistant and sensible variants in the four morphotype populations.

\begin{tabular}{lcccc}
\hline & Diffuse & Ring & Edged & Opaque \\
\hline Tested isolates & 28 & 23 & 21 & 16 \\
Non-modified isolates* & 27 & 15 & 13 & 9 \\
Resistant isolates & 1 & 6 & 8 & 6 \\
Sensitive isolates & 0 & 2 & 0 & 1 \\
$P^{* *}$ & 1 & $<0.040$ & $<0.007$ & $<0.040$ \\
Percent of resistants & 3.5 & 26 & 38 & 37.5 \\
\hline
\end{tabular}

* Isolates exhibiting an inhibition area comparable to that of the strain CNRZ368.

** Probability that the frequency of menadione-resistant isolates in each colonial morphotype was similar to that observed in the diffuse morphotype.

resistance. Finally, sensitive clones were regrouped in a third class and were found to be in a minority $(3 / 88)$.

The menadione tolerance was then correlated with the clone colonial phenotype and is presented in Table I. It appears that the three populations of variants (ring, edged and opaque) are statistically different from the diffuse one, since they contain a larger proportion of resistant isolates. No more than $3.5 \%$ of diffuse clones were resistant to menadione, whereas this rate reached 26 to $38 \%$ for the three other phenotypes. Enrichment in menadione-resistants is thus observed in the variants compared to the predominant colonial phenotype.

Concerning the sensitive variants, the sample was not representative enough to lead to a conclusion. However, this analysis allowed the isolation of three sensitive clones (two ring and one opaque).

\section{CONCLUSION}

In spite of being anaerobic, Streptococcus thermophilus disposes of an inducible defence system against $\mathrm{H}_{2} \mathrm{O}_{2}$ and against menadione. The question remains as to whether these two responses result from the induction of two distinct regulons, as in E. coli [3], or of a single one. However, the defence against $\mathrm{H}_{2} \mathrm{O}_{2}$ appears to be inducible and adaptative, and depends on the physiological state of the cells.

Moreover, the variability of menadionetolerance is a new aspect of $S$. thermophilus instability, which seems to be linked to 
colonial polymorphism. Thus, selection of conditional colonial variants may constitute an efficient preliminary screen allowing simple selection for variants resistant to oxidative agents like menadione.

\section{REFERENCES}

[1] Christman M.F., Morgan R.W., Jacobson F.S. Ames B.N., Positive control of a regulon for defences against oxidative stress and some heatshock proteins in Salmonella typhimurium, Cell 41 (1985) 753-762.

[2] Crawford D.R., Davies J.A., Adaptative response and oxidative stress, Environ. Health Perspect. 102 (1994) 25-28.

[3] Farr S.B., Kogoma T., Oxidative stress responses in Escherichia coli and Salmonella typhimurium, Microbiol. Rev. 55 (1991) 561-585.

[4] Flint D., Tuminello J., Emptage M., The inactivation of $\mathrm{Fe}-\mathrm{S}$ cluster containing hydro-lyases by superoxide, J. Biol. Chem. 268 (1993) 22369-22376.

[5] Gardner P.R., Fridovich I., Superoxide sensitivity of Escherichia coli 6-phosphogluconate dehydratase, J. Biol. Chem. 266 (1991) 1478-1483.

[6] Gardner P.R., Fridovich I., Superoxide sensitivity of Escherichia coli aconitase, J. Biol. Chem. 266 (1991) 19328-19333.
[7] Gaudu P., Touati D., Niviere V., Fontecave M., The NAD(P)H: flavine oxidoreductase from Escherichia coli as a source of superoxide radicals, J. Biol. Chem. 269 (1994) 8182-8188.

[8] Gonzalez-Flecha B., Demple B., Metabolic source of hydrogen peroxide in aerobically growing Escherichia coli, J. Biol. Chem. 270 (1995) 13681-13687.

[9] Halliwell B., Gutteridge J.M.C., Lipid peroxidation, oxigen radicals, transition metals and diseases, Biochem. J. 219 (1984) 1-14.

[10] Imlay J.A., A metabolic enzyme that rapidly produces superoxide, fumarate reductase of Escherichia coli, J. Biol. Chem. 270 (1995) 19767-19777.

[11] Imlay J.A., Linn S., DNA damage and oxygen radical toxicity, Sciences 240 (1988) 1302-1309.

[12] Jenkins D.E., Schultz J.E., Matin A., Starvation-induced cross protection against heat or $\mathrm{H}_{2} \mathrm{O}_{2}$ challenge in Escherichia coli, J. Bacteriol. 170 (1988) 3910-3914.

[13] Messner K.R., Imlay J.A., The identification of primary sites of superoxide and hydrogen peroxide formation in the aerobic respiratory chain and sulfite reductase complex of Escherichia coli, J. Biol. Chem. 274 (1999) 10119-10128.

[14] Pébay M., Colmin C., Guédon G., Simonet J.M., Decaris B., Chromosomal genetic instability in Streptococcus thermophilus, Lait 73 (1993) 181-190.

[15] Storz G., Christman M.F., Sies H., Ames B.N. Spontaneous mutagenesis and oxidative damage to DNA in Salmonella typhimurium, Proc. Natl. Acad. Sci. USA 84 (1987) 8917-8921. 